\title{
REVISION SURVEY OF NON-MARINE AQUATIC MOLLUSCS (GASTROPODA, BIVALVIA) OF KRK ISLAND (CROATIA)
}

\author{
Luboš BERAN* \\ Nature Conservation Agency of the Czech Republic, Regional Office Kokořínsko - Máchův kraj \\ Protected Landscape Area Administration, Česká 149, CZ-276 01 Mělník, Czech Republic
}

Beran, L.: Revision survey of non-marine aquatic molluscs (Gastropoda, Bivalvia) of Krk Island (Croatia). Nat. Croat., Vol. 27, No. 1., 211-224, 2018, Zagreb.

The survey of aquatic non-marine molluscs of the largest island in the Adriatic Sea done in the years 2015-2017 confirmed the occurrence of 28 species (18 freshwater and 4 brackish gastropods, 6 bivalves) at 72 sites, while previous research done about 60 years before found out only 7 species. Results of this research were compared with aquatic molluscan assemblages of other Croatian islands and the number of recorded species is the highest known of the islands in the Adriatic Sea. The probable reason for this relatively high diversity is the existence of various habitats together with the facts that it is the largest island in the Adriatic Sea, and is also relatively close to the mainland.

Key words: Mollusca, Gastropoda, Bivalvia, Krk Island, Croatia, faunistics

Beran, L.: Pregled istraživanja nemorskih vodenih mekušaca (Gastropoda, Bivalvia) otoka Krka (Hrvatska). Nat. Croat., Vol. 27, No. 1., 211-224, 2018, Zagreb.

Istraživanje nemorskih vodenih mekušaca provedeno na najvećem jadranskom otoku tijekom 2015.2017., na 72 lokaliteta potvrdilo je postojanje 28 vrsta (18 slatkovodnih vrsta i 4 vrste puževa boćatih voda, te 6 vrsta školjkaša), dok je prethodno istraživanje otprije otprilike 60 godina navodilo samo 7 vrsta. Rezultati ovog istraživanja uspoređeni su sa vrstama vodenih mekušaca drugih hrvatskih otoka, a njihov broj je ovdje najveći među svim jadranskim otocima. Najvjerojatniji razlog za tu relativno visoku biološku raznolikost je postojanje različitih staništa na otoku, kao i činjenica da se radi o najvećem jadranskom otoku koji je i relativno blizu kopna.

Ključne riječi: Mollusca, Gastropoda, Bivalvia, otok Krk, Hrvatska, faunistika

\section{INTRODUCTION}

Krk is the largest island in the Adriatic Sea. Non-marine molluscs of this island were studied by the famous Slovenian malacologist J. Bole about 60 years ago from 1950 to 1957 (Bole, 1958). Only seven non-marine aquatic species (Pseudamnicola conovula, Galba truncatula, Stagnicola fuscus, Radix auricularia, Gyraulus laevis, Musculium lacustre, Pisidium duplicatum) were found. The main aim of this research was to provide a new inventory of aquatic molluscs inhabiting this island and compare it with the results of previous research.

\footnotetext{
* e-mail: lubos.beran@nature.cz
} 


\section{MATERIAL AND METHODS}

Data were obtained from field surveys conducted in the years 2015-2017. Only non-marine aquatic (freshwater, brackish) molluscs were studied. Altogether 72 sites at which aquatic molluscs occurred were studied, sites comprising springs, wells, ditches, rivulets, small brooks, pools and also seacoast and lagoons. The main sampling method used for field research was washing vegetation or sediments using a metal sieve (diameter $20 \mathrm{~cm}$, mesh size $0.8 \mathrm{~mm}$ ) combined with hand collection after the surfaces of plants, stones, wood and artificial materials (e.g. plastic bags and bottles) were searched. Wells were studied using this sieve on 2.5-3 m long stick.

Molluscs were classified using various shell characteristics or dissected and then identified using their copulatory organs if identification based solely on the shell was impossible. Specimens for dissection were killed in hot water and then fixed in 80\% ethanol. Selected material of shells and killed specimens in $80 \%$ ethanol is deposited in the author's collection.

\section{STUDY AREA}

Krk Island, with an area of $410 \mathrm{~km}^{2}$ and $38 \mathrm{~km}$ long by $21 \mathrm{~km}$ wide is the largest island in the Adriatic Sea. The northern part of the island is lower and the southern part is characterized by an abundance of karst plateaus. The highest peak is Obzova with an altitude of $568 \mathrm{~m}$. Two fairly large water bodies (Ponikve lake, Jezero Njivice lake) are situated in the central part of this island. Permanent watercourses are rare; the biggest is the Ričica Brook in the southern part of the island. There are many small and isolated pools on this island.

\section{LIST OF INVESTIGATED SITES}

Data in the list are as follows: site number, geographical co-ordinates, name of the nearest settlement, description of the site, date of investigation. Sites are depicted in Fig. 1.

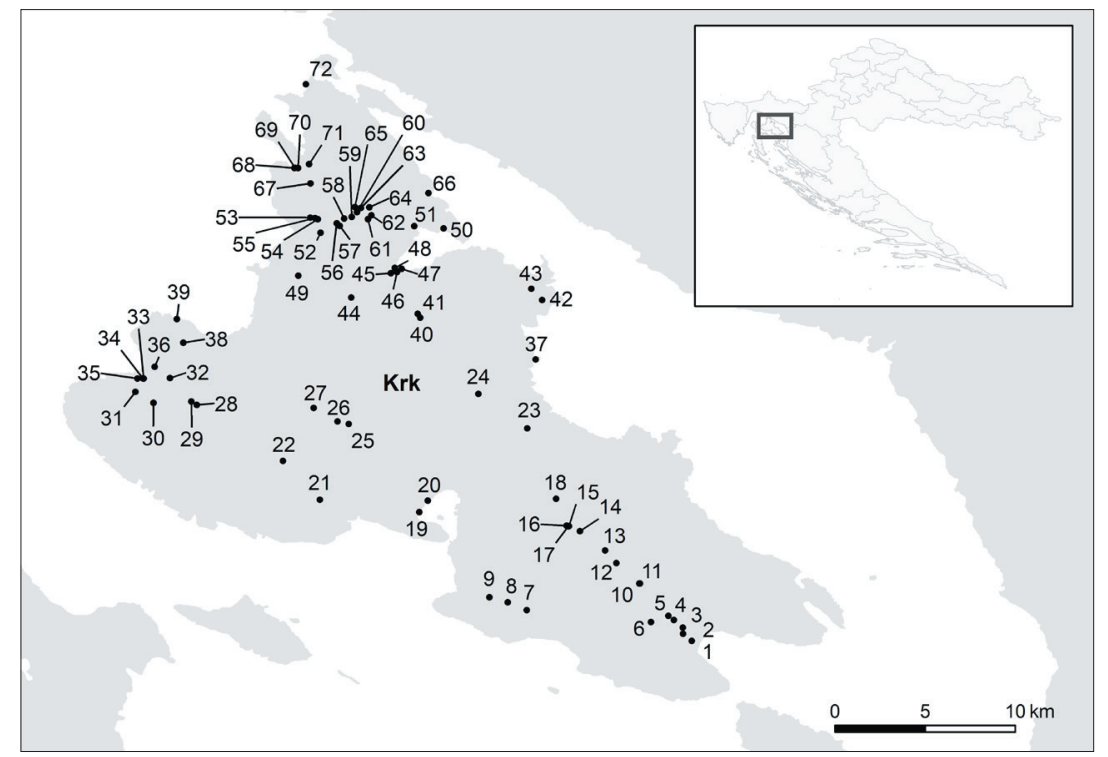

Fig. 1. The map of Krk Island with sites under study. Orig. H. Medková. 
$1-44^{\circ} 57^{\prime} 53.0^{\prime \prime} \mathrm{N}, 14^{\circ} 44^{\prime} 39.2^{\prime \prime} \mathrm{E}$, Baška, the Ričica Brook ca $250 \mathrm{~m}$ upstream of its inflow into the sea, 24.8.2015;

$2-44^{\circ} 58^{\prime} 05.7^{\prime \prime} \mathrm{N}, 14^{\circ} 44^{\prime} 23.5^{\prime \prime} \mathrm{E}$, Baška, a small tributary of the Ričica Brook about $100 \mathrm{~m}$ upstream of its inflow into the Ričica Brook, 29.12.2015;

$3-44^{\circ} 58^{\prime} 16.9^{\prime \prime} \mathrm{N}, 1^{\circ} 44^{\prime} 23.1^{\prime \prime} \mathrm{E}$, Baška, the Ričica Brook ca $1200 \mathrm{~m}$ upstream of its inflow into the sea, a) 24.8.2015, b) 29.12.2015;

$4-44^{\circ} 58^{\prime} 30.3^{\prime \prime} \mathrm{N}, 14^{\circ} 44^{\prime} 06.9^{\prime \prime} \mathrm{E}$, Jurandvor, the Ričica Brook by the bridge in Jurandvor, 29.12.2015;

$5-44^{\circ} 58^{\prime} 37.6^{\prime \prime} \mathrm{N}, 14^{\circ} 43^{\prime} 57.2^{\prime \prime} \mathrm{E}$, Jurandvor, the Ričica Brook by the small bridge (Fig. 3), 1.8.2017;

$6-44^{\circ} 58^{\prime} 26.6^{\prime \prime} \mathrm{N}, 14^{\circ} 43^{\prime} 26.1^{\prime \prime} \mathrm{E}$, Batomalj, a small spring to the west of Batomalj, 1.8.2017;

$7-44^{\circ} 58^{\prime} 48.1^{\prime \prime} \mathrm{N}, 14^{\circ} 39^{\prime} 43.1^{\prime \prime} \mathrm{E}$, Stara Baška, a pool to the north of the Svinsko hill (238 m a. s. 1.), 27.12.2016;

$8-44^{\circ} 59^{\prime} 01.8^{\prime \prime} \mathrm{N}, 14^{\circ} 39^{\prime} 08.9^{\prime \prime} \mathrm{E}$, Stara Baška, the overgrown pool by the Punat - Stara Baška road, 25.8.2016;

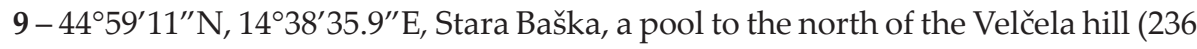
$\mathrm{m}$ a. s. 1.), 27.12.2016;

$10-44^{\circ} 59^{\prime} 35.9^{\prime \prime} \mathrm{N}, 1^{\circ} 43^{\prime} 04.9^{\prime \prime} \mathrm{E}$, Draga Bašćanska, the dried Ričica Brook in Draga Bašćanska near the cemetery, 24.8.2015;

$11-44^{\circ} 59^{\prime} 35.8^{\prime \prime} \mathrm{N}, 14^{\circ} 43^{\prime} 06.3^{\prime \prime} \mathrm{E}$, Draga Bašćanska, a small rivulet near its inflow into the Ričica Brook in Draga Bašćanska near the cemetery, 24.8.2015;

$12-45^{\circ} 00^{\prime} 12.2^{\prime \prime} \mathrm{N}, 14^{\circ} 42^{\prime} 23.8^{\prime \prime} \mathrm{E}$, Draga Bašćanska, pools in the dried Ričica Brook ca $500 \mathrm{~m}$ upstream of Draga Bašćanska, 24.8.2015;

$13-45^{\circ} 00^{\prime} 35.1^{\prime \prime} \mathrm{N}, 14^{\circ} 42^{\prime} 03.5^{\prime \prime} \mathrm{E}$, Draga Bašćanska, the Ričica Brook ca $2000 \mathrm{~m}$ upstream of Draga Bašćanska, 1.8.2017;

$14-45^{\circ} 01^{\prime} 09.5^{\prime \prime} \mathrm{N}, 14^{\circ} 41^{\prime} 18.2^{\prime \prime} \mathrm{E}$, Draga Bašćanska, the Ričica Brook ca $2500 \mathrm{~m}$ upstream of Draga Bašćanska, 29.12.2015;

$15-45^{\circ} 01^{\prime} 18.4^{\prime \prime} \mathrm{N}, 14^{\circ} 40^{\prime} 58.7^{\prime \prime} \mathrm{E}$, Draga Bašćanska, pools in the dried Ričica Brook near Žanac spring, 24.8.2015;

$16-45^{\circ} 01^{\prime} 19.3^{\prime \prime} \mathrm{N}, 14^{\circ} 40^{\prime} 54.6^{\prime \prime} \mathrm{E}$, Draga Bašćanska, Žanac spring by the Krk - Baška road, 24.8.2015;

$17-45^{\circ} 01^{\prime} 18.2^{\prime \prime} \mathrm{N}, 14^{\circ} 40^{\prime} 57.4^{\prime \prime} \mathrm{E}$, Draga Bašćanska, an underground reservoir by Žanac spring near the Krk - Baška road, a) 29.12.2016, b) 1.8.2017;

$18-45^{\circ} 02^{\prime} 07.6^{\prime \prime} \mathrm{N}, 14^{\circ} 40^{\prime} 35.5^{\prime \prime} \mathrm{E}$, Draga Bašćanska, pools in the dried Ričica Brook in a valley by a big isolated rock, 24.8.2015;

$19-45^{\circ} 01^{\prime} 43.6^{\prime \prime} \mathrm{N}, 14^{\circ} 36^{\prime} 29.9^{\prime \prime} \mathrm{E}, \mathrm{Krk}$, coastline in Puntarska draga opposite of island (Sv. Bernard), 28.8.2015;

20 - 45 $02^{\prime} 04.2^{\prime \prime} \mathrm{N}, 14^{\circ} 36^{\prime} 45.4^{\prime \prime} \mathrm{E}, \mathrm{Krk}$, a small lagoon in Puntarska draga, 28.8.2015;

$21-45^{\circ} 02^{\prime} 05.9^{\prime \prime} \mathrm{N}, 14^{\circ} 33^{\prime} 31.3^{\prime \prime} \mathrm{E}, \mathrm{Krk}$, the quite extensive Kimpi pool by the Salatići - Krk road, 29.8.2016;

$22-45^{\circ} 03^{\prime} 15.3^{\prime \prime} \mathrm{N}, 14^{\circ} 32^{\prime} 25.3^{\prime \prime} \mathrm{E}, \mathrm{Kosic}$, a small pool by the dirt road to the southeast of Kosić, 28.12.2016; 
$23-45^{\circ} 04^{\prime} 13.7^{\prime \prime} \mathrm{N}, 14^{\circ} 39^{\prime} 43.8^{\prime \prime} \mathrm{E}$, Vrbnik, the artificial canal by the Vrbnik - Krk road near the crossroad, 27.8.2015;

$24-45^{\circ} 05^{\prime} 15.6^{\prime \prime} \mathrm{N}, 14^{\circ} 38^{\prime} 16.2^{\prime \prime} \mathrm{E}$, Vrbnik, a small spring and brook in a vineyard northeast of Vrbnik, 27.12.2015;

$25-45^{\circ} 04^{\prime} 21.6^{\prime \prime} \mathrm{N}, 14^{\circ} 34^{\prime} 23.4^{\prime \prime} \mathrm{E}$, Malinska, pools on the eastern edge of Ponikve lake, 27.12.2015;

$26-45^{\circ} 04^{\prime} 26.1^{\prime \prime} \mathrm{N}, 14^{\circ} 34^{\prime} 03^{\prime \prime} \mathrm{E}$, Malinska, on the east edge of Ponikve lake, 27.12.2015;

$27-45^{\circ} 04^{\prime} 50.2^{\prime \prime} \mathrm{N}, 14^{\circ} 33^{\prime} 20.5^{\prime \prime} \mathrm{E}$, Malinska, western bank of Ponikve lake, 22.8.2015;

$28-45^{\circ} 04^{\prime} 55.8^{\prime \prime} \mathrm{N}, 14^{\circ} 29^{\prime} 50.7^{\prime \prime} \mathrm{E}$, Poljica, the pool by the dirt road to the southeast of Poljica, 29.8.2016;

$29-45^{\circ} 05^{\prime} 01.8^{\prime \prime} \mathrm{N}, 14^{\circ} 29^{\prime} 40.7^{\prime \prime} \mathrm{E}$, Poljica, the pool Menkova Lokva on the southeastern edge of Poljica (Fig. 4), 29.8.2016;

$30-45^{\circ} 04^{\prime} 59.4^{\prime \prime} \mathrm{N}, 14^{\circ} 28^{\prime} 32.7^{\prime \prime} \mathrm{E}$, Poljica, a small dried pool by the Poljica - Milohnići dirt road near Kukurik (176 m a. s. 1.), 28.8.2016;

$31-45^{\circ} 05^{\prime} 19^{\prime \prime} \mathrm{N}, 14^{\circ} 28^{\prime} 00.3^{\prime \prime} \mathrm{E}$, Milohnići, two small pools (Ormatine) to the northeast of Milohnići, 28.8.2016;

$32-45^{\circ} 05^{\prime} 44^{\prime \prime} \mathrm{N}, 14^{\circ} 29^{\prime} 02.3^{\prime \prime} \mathrm{E}$, Poljica, a pool near a dirt road ca $1500 \mathrm{~m}$ to the southwest of Poljica, 28.8.2016;

33- $45^{\circ} 05^{\prime} 43.1^{\prime \prime} \mathrm{N}, 14^{\circ} 28^{\prime} 15.3^{\prime \prime} \mathrm{E}$, Poljica, the pool next to the "smaller" big oak ca 100 $\mathrm{m}$ to the east of the Volovska pool, 28.8.2016;

$34-45^{\circ} 05^{\prime} 43.6^{\prime \prime} \mathrm{N}, 14^{\circ} 28^{\prime} 13.7^{\prime \prime} \mathrm{E}$, Poljica, the Volovska pool next to the big oak, 28.8.2016;

$35-45^{\circ} 05^{\prime} 43^{\prime \prime} \mathrm{N}, 14^{\circ} 28^{\prime} 03.9^{\prime \prime} \mathrm{E}$, Poljica, a dried pool ca $200 \mathrm{~m}$ to the west of the Volovska pool, 28.8.2016;

$36-45^{\circ} 06^{\prime} 04^{\prime \prime} \mathrm{N}, 14^{\circ} 28^{\prime} 34.8^{\prime \prime} \mathrm{E}$, Poljica, the Rnjeva pool by the dirt road between Poljica and Uvala (cove) Čavlena, 28.8.2016;

$37-45^{\circ} 06^{\prime} 17,2^{\prime \prime} \mathrm{N}, 14^{\circ} 39^{\prime} 59.1^{\prime \prime} \mathrm{E}$, Risika, a rocky seacoast near Sv. Marak, 4.8.2017;

$38-45^{\circ} 06^{\prime} 47,2^{\prime \prime} \mathrm{N}, 14^{\circ} 29^{\prime} 26.2^{\prime \prime} \mathrm{E}$, Porat, a pool to the south of Porat, 3.8.2017;

$39-45^{\circ} 07^{\prime} 29.7^{\prime \prime} \mathrm{N}, 14^{\circ} 29^{\prime} 14.8^{\prime \prime} \mathrm{E}$, Porat, a rocky seacoast in Uvala (cove) Uhlić near Porat, 3.8.2017;

$40-45^{\circ} 07^{\prime} 32.1^{\prime \prime} \mathrm{N}, 14^{\circ} 36^{\prime} 31.7^{\prime \prime} \mathrm{E}$, Dobrinj, dried canals in park by the road to the southeast of Dobrinj, 25.8.2015;

$41-45^{\circ} 07^{\prime} 39.1^{\prime \prime} \mathrm{N}, 1^{\circ} 36^{\prime} 27.1^{\prime \prime} \mathrm{E}$, Dobrinj, a small pool in a dried brook near Dobrinj, 4.8.2017;

$42-45^{\circ} 08^{\prime} 03.8^{\prime \prime} \mathrm{N}, 14^{\circ} 40^{\prime} 10.4^{\prime \prime} \mathrm{E}$, Šilo, a pool to the south of Šilo, 26.12.2016;

$43-45^{\circ} 08^{\prime} 24.0^{\prime \prime} \mathrm{N}, 14^{\circ} 39^{\prime} 51.0^{\prime \prime} \mathrm{E}$, Šilo, a small pool by the dirt road to the south of Šilo, 26.12.2016;

$44-45^{\circ} 08^{\prime} 08.2^{\prime \prime} \mathrm{N}, 14^{\circ} 34^{\prime} 28.0^{\prime \prime} \mathrm{E}$, Tribulje, two small isolated pools (Mokratka) to the west of Klanice, 30.12.2015;

$45-45^{\circ} 08^{\prime} 51.7^{\prime \prime} \mathrm{N}, 14^{\circ} 35^{\prime} 38.9^{\prime \prime} \mathrm{E}$, Soline, a small ditch by the Čižići - Tribulje road, 2.8.2017;

$46-45^{\circ} 08^{\prime} 54.0^{\prime \prime} \mathrm{N}, 14^{\circ} 35^{\prime} 50.2^{\prime \prime} \mathrm{E}$, Soline, a dried brook ca $250 \mathrm{~m}$ from its inflow into the sea, 26.8.2015; 
$47-45^{\circ} 08^{\prime} 59.6^{\prime \prime} \mathrm{N}, 14^{\circ} 35^{\prime} 58.4^{\prime \prime} \mathrm{E}$, Soline, a destroyed reed swamp by the road near a beach near Soline, 26.8.2015;

$48-45^{\circ} 09^{\prime} 01.3^{\prime \prime} \mathrm{N}, 14^{\circ} 35^{\prime} 46.2^{\prime \prime} \mathrm{E}$, Soline, a small pool by the road ca $70 \mathrm{~m}$ from the crossroad, 26.8.2015;

$49-45^{\circ} 08^{\prime} 47.2^{\prime \prime} \mathrm{N}, 14^{\circ} 32^{\prime} 52.7^{\prime \prime} \mathrm{E}$, Njivice, a pool by the road ca $200 \mathrm{~m}$ to the south of the cemetery, 25.8.2015;

$50-45^{\circ} 10^{\prime} 12.2^{\prime \prime} \mathrm{N}, 14^{\circ} 37^{\prime} 13.6^{\prime \prime} \mathrm{E}$, Čižići, a brackish pool near Zaljev Soline to the northeast of Čižići, 26.12.2016;

$51-45^{\circ} 10^{\prime} 16.2^{\prime \prime} \mathrm{N}, 14^{\circ} 36^{\prime} 20.9^{\prime \prime} \mathrm{E}$, Čižići, an extensive pool and wetland by the Čižići - Rudine road, a) 26.12.2016, b) 2.8.2017;

$52-45^{\circ} 10^{\prime} 04.1^{\prime \prime} \mathrm{N}, 14^{\circ} 33^{\prime} 32.8^{\prime \prime} \mathrm{E}$, Njivice, the southwestern part of Jezero Njivice lake (Fig. 2), 23.8.2015;

$53-45^{\circ} 10^{\prime} 31.3^{\prime \prime} \mathrm{N}, 14^{\circ} 33^{\prime} 14.2^{\prime \prime} \mathrm{E}$, Njivice, an artificial canal ca $100 \mathrm{~m}$ to the west of the road, 27.8.2015;

$54-45^{\circ} 10^{\prime} 28.5^{\prime \prime} \mathrm{N}, 14^{\circ} 33^{\prime} 27.8^{\prime \prime} \mathrm{E}$, Njivice, the northwestern edge of Jezero Njivice lake, 29.8.2016;

$55-45^{\circ} 10^{\prime} 30.8^{\prime \prime} \mathrm{N}, 14^{\circ} 33^{\prime} 22.9^{\prime \prime} \mathrm{E}$, Njivice, a canal on the northern edge of Jezero Njivice lake, 25.8.2015;

$56-45^{\circ} 10^{\prime} 21.1^{\prime \prime} \mathrm{N}, 14^{\circ} 34^{\prime} 02.1^{\prime \prime} \mathrm{E}, \mathrm{Njivice}$, a canal on the northeastern edge of Jezero Njivice lake, 28.12.2015;

$57-45^{\circ} 10^{\prime} 16.6^{\prime \prime} \mathrm{N}, 14^{\circ} 34^{\prime} 07.1^{\prime \prime} \mathrm{E}, \mathrm{Njivice}$, the dried eastern part of Jezero Njivice lake, 25.8.2015;

$58-45^{\circ} 10^{\prime} 29.9^{\prime \prime} \mathrm{N}, 14^{\circ} 34^{\prime} 15.2^{\prime \prime} \mathrm{E}$, Njivice, small pools in a dried artificial canal to the northeast of Jezero Njivice lake, a) 26.8.2015, b) 28.12.2015;

$59-45^{\circ} 10^{\prime} 32.6^{\prime \prime} \mathrm{N}, 14^{\circ} 34^{\prime} 28.8^{\prime \prime} \mathrm{E}$, Njivice, a small pool on the way to the house to the northeast of Jezero Njivice lake, 30.12.2015;

$60-45^{\circ} 10^{\prime} 41.5^{\prime \prime} \mathrm{N}, 14^{\circ} 34^{\prime} 38.2^{\prime \prime} \mathrm{E}$, Njivice, pools in pastures (Veliki lug) to the northeast of Jezero Njivice lake, 28.12.2015;

$61-45^{\circ} 10^{\prime} 28.4^{\prime \prime} \mathrm{N}, 14^{\circ} 34^{\prime} 57.7^{\prime \prime} \mathrm{E}$, Čižići, a temporary ditch in the central part of pastures (Mali lug) to the east of Jezero Njivice lake, 30.12.2015;

$62-45^{\circ} 10^{\prime} 35.5^{\prime \prime} \mathrm{N}, 14^{\circ} 35^{\prime} 04.1^{\prime \prime} \mathrm{E}$, Čižići, a temporary ditch on the northern edge of pastures (Mali lug) to the northeast of Jezero Njivice lake, 30.12.2015;

$63-45^{\circ} 10^{\prime} 48.7^{\prime \prime} \mathrm{N}, 14^{\circ} 34^{\prime} 45.0^{\prime \prime} \mathrm{E}$, Njivice, a dried ditch in pastures (Veliki lug) to the northeast of Jezero Njivice lake, 26.8.2015;

$64-45^{\circ} 10^{\prime} 50.0^{\prime \prime} \mathrm{N}, 14^{\circ} 35^{\prime} 00.2^{\prime \prime} \mathrm{E}$, Njivice, a ditch on the northern edge of pastures (Veliki lug) to the northeast of Jezero Njivice lake, 28.12.2015;

65- $45^{\circ} 10^{\prime} 50.2^{\prime \prime} \mathrm{N}, 14^{\circ} 34^{\prime} 34.3^{\prime \prime} \mathrm{E}$, Njivice, flooded pastures in Veliki lug to the northeast of Jezero Njivice lake, 29.12.2016;

$66-45^{\circ} 11^{\prime} 15.5^{\prime \prime} \mathrm{N}, 14^{\circ} 36^{\prime} 46.5^{\prime \prime} \mathrm{E}$, Rudine, a rocky seacoast at Uvala (cove) Slivanjska, 2.8.2017;

$67-45^{\circ} 11^{\prime} 32.6^{\prime \prime} \mathrm{N}, 14^{\circ} 33^{\prime} 14.6^{\prime \prime} \mathrm{E}$, Omišalj, a pool in a dried concrete canal to the south of Omišalj, 28.12.2015;

$68-45^{\circ} 12^{\prime} 00.1^{\prime \prime} \mathrm{N}, 14^{\circ} 32^{\prime} 45.8^{\prime \prime} \mathrm{E}$, Omišalj, the western concrete water reservoir in a factory to the south of Omišalj, 30.7.2017; 
$69-45^{\circ} 12^{\prime} 00.8^{\prime \prime} \mathrm{N}, 14^{\circ} 32^{\prime} 46.6^{\prime \prime} \mathrm{E}$, Omišalj, the eastern concrete water reservoir in a factory to the south of Omišalj, 30.7.2017;

$70-45^{\circ} 12^{\prime} 00.3^{\prime \prime} \mathrm{N}, 14^{\circ} 32^{\prime} 52.4^{\prime \prime} \mathrm{E}$, Omišalj, a small pool in a dried concrete canal in a factory to the south of Omišalj, 30.7.2017;

$71-45^{\circ} 12^{\prime} 07.3^{\prime \prime} \mathrm{N}, 14^{\circ} 33^{\prime} 12.2^{\prime \prime} \mathrm{E}$, Omišalj, a small ditch to the south of Omišalj, 30.7.2017;

$72-45^{\circ} 14^{\prime} 30.4^{\prime \prime} \mathrm{N}, 14^{\circ} 33^{\prime} 06.4^{\prime \prime} \mathrm{E}$, Omišalj, a small brackish wetland near Krčki most bridge (Rt Šilo), 30.12.2015;

\section{RESULTS}

The survey of aquatic non-marine molluscs of the largest island in the Adriatic Sea confirmed the occurrence of 28 species (18 freshwater and 4 brackish gastropods, 6 bivalves) at 72 sites. A list of molluscs found at particular sites and their density are shown at Tabs. 1-4. In the case of two species (Iglica forumjuliana, Kerkia sp.) only shells were collected so their identification is only preliminary.

More diversified molluscan assemblages with 4-6 species were found at only 15 sites. Probably the most diversified assemblages inhabit Jezero Njivice lake (sites 52-57) (Fig. 2) and its surroundings with the species Bithynia tentaculata, Valvata cristata, Acroloxus lacustris, Stagnicola fuscus, Anisus spirorbis, Gyraulus albus, G. crista, Hippeutis complanatus, Pisidium obtusale, P. personatum. The molluscs Valvata cristata and Hippeutis complanatus were found only there. Numerous and mostly temporary ditches and pools on pastures (sites 58-65) in the surroundings of this lake were inhabited most often only with Anisus spirorbis. Stagnicola fuscus, Radix auricularia, Gyraulus albus, G. crista, Pisidium milium and P. obtusale were found at Ponikve lake (sites 25-27). Different assemblages inhabit the Ričica Brook and its tributaries (sites 1-5, 10-15, 18) (Fig. 3). The species Pseudamnicola conovula, Radix labiata, Ancylus fluviatilis and less often also Galba truncatula or Pisidium personatum occurr there. Pseudamnicola conovula was found also in Žanac Spring (site 16) near this brook but Ancylus fluviatilis inhabits only Ričica Brook. Gastropods Graziana pupula, Iglica forumjuliana and Kerkia sp. were found only in the undeground (site 18). Small and isolated pools (sites 7-9, 21, 22, 28-36, 38, 42-44, $48,49,51$ ) (Fig. 4, 5) belong to very common freshwater habitats and are situated in different locations on Krk Island. Their molluscan fauna is very poor and usually consists of fewer than 3 species and situations in which no molluscs were found were not rare. The gastropods Galba truncatula, Radix auricularia, Ferrissia fragilis and the bivalve Musculium lacustre are the most common inhabitants while Acroloxus lacustris, Stagnicola fuscus, Anisus spirorbis, Gyraulus crista were found less often.

Ecrobia ventrosa, Truncatella subcylindrica, Ovatella firminii and Myosotella myosotis are species inhabiting brackish waters. The first one was found at only one site (site 50) in the brackish pool. M. myosotis occurs in muddy wetlands along the coast while T. subcylindrica and O. firminii inhabit rocky coasts (Fig. 6).

Only 7 species (P. conovula, G. truncatula, S. fuscus, R. auricularia, R. labiata, A. spirorbis, F. fragilis) were found at 10 and more sites. Galba truncatula is the most widespread species on this island and its occurrence was confirmed at 20 sites. On the other hand, 8 species (E. ventrosa, I. forumjuliana, G. pupula, K. sp., T. subcylindrica, P. acuta, P. casertanum, P. subtruncatum) were recorded at only one site (Tabs. 1-4).

Two recorded species, Physa acuta and Ferrissia fragilis, belong to non-native species. 


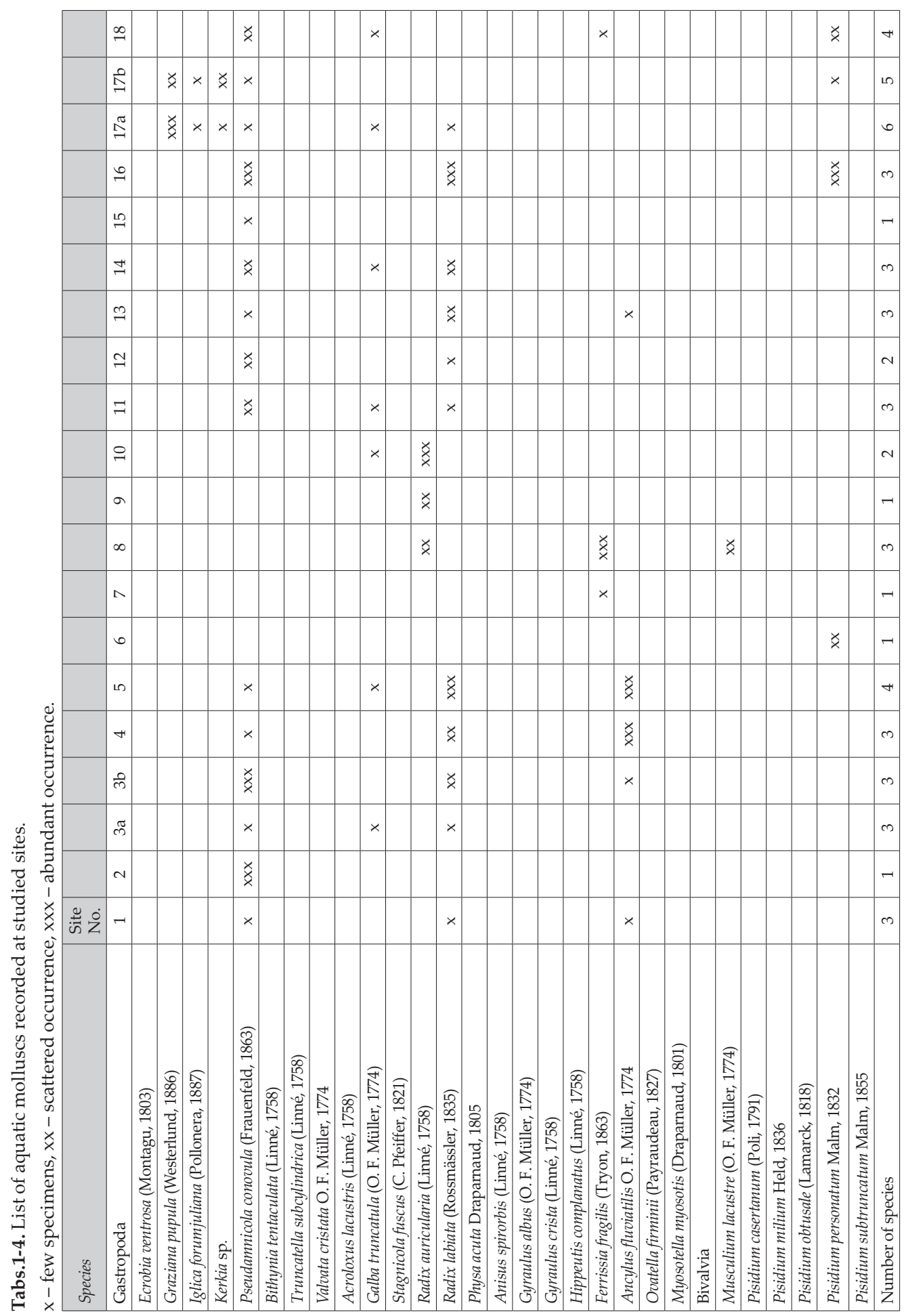




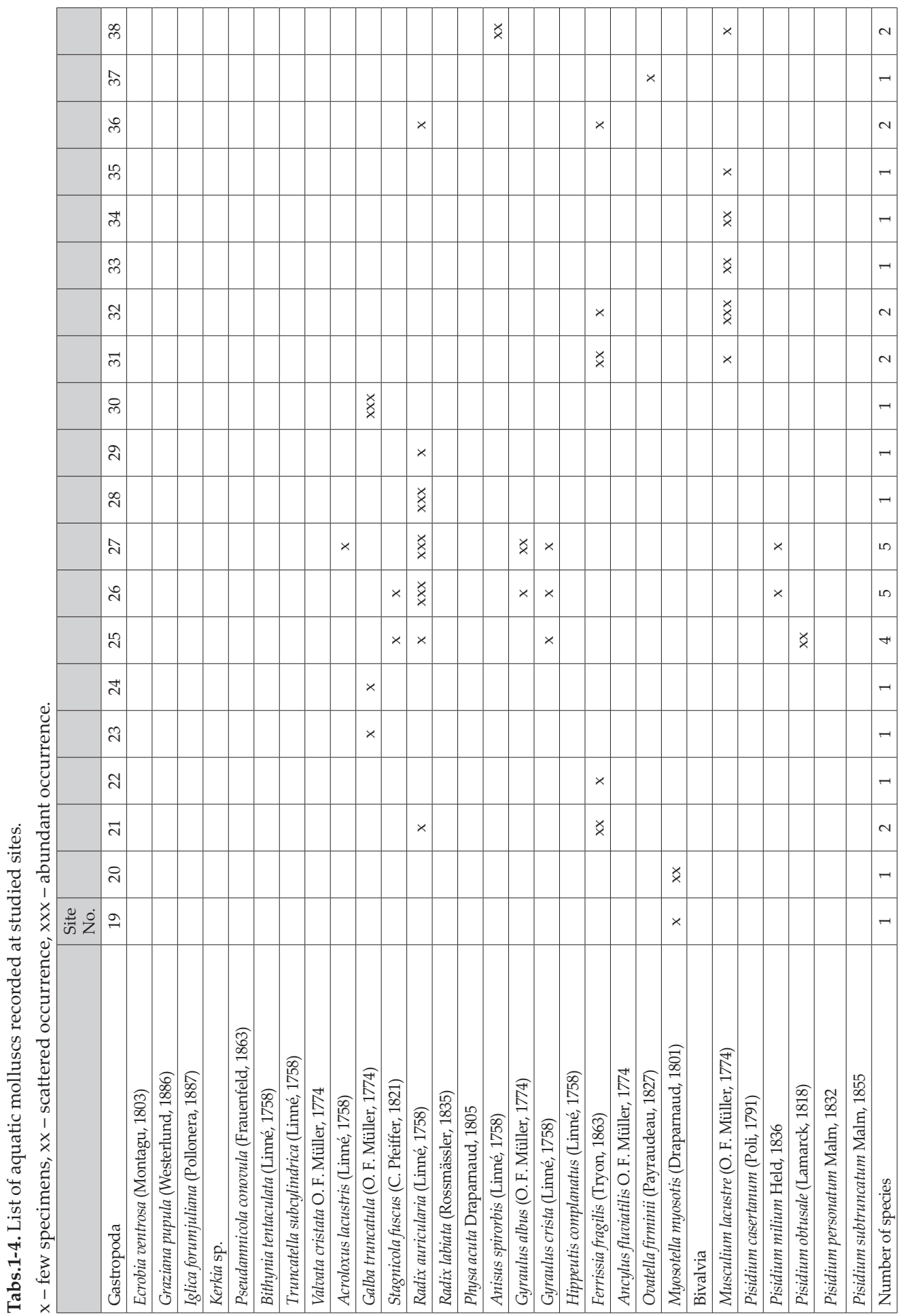




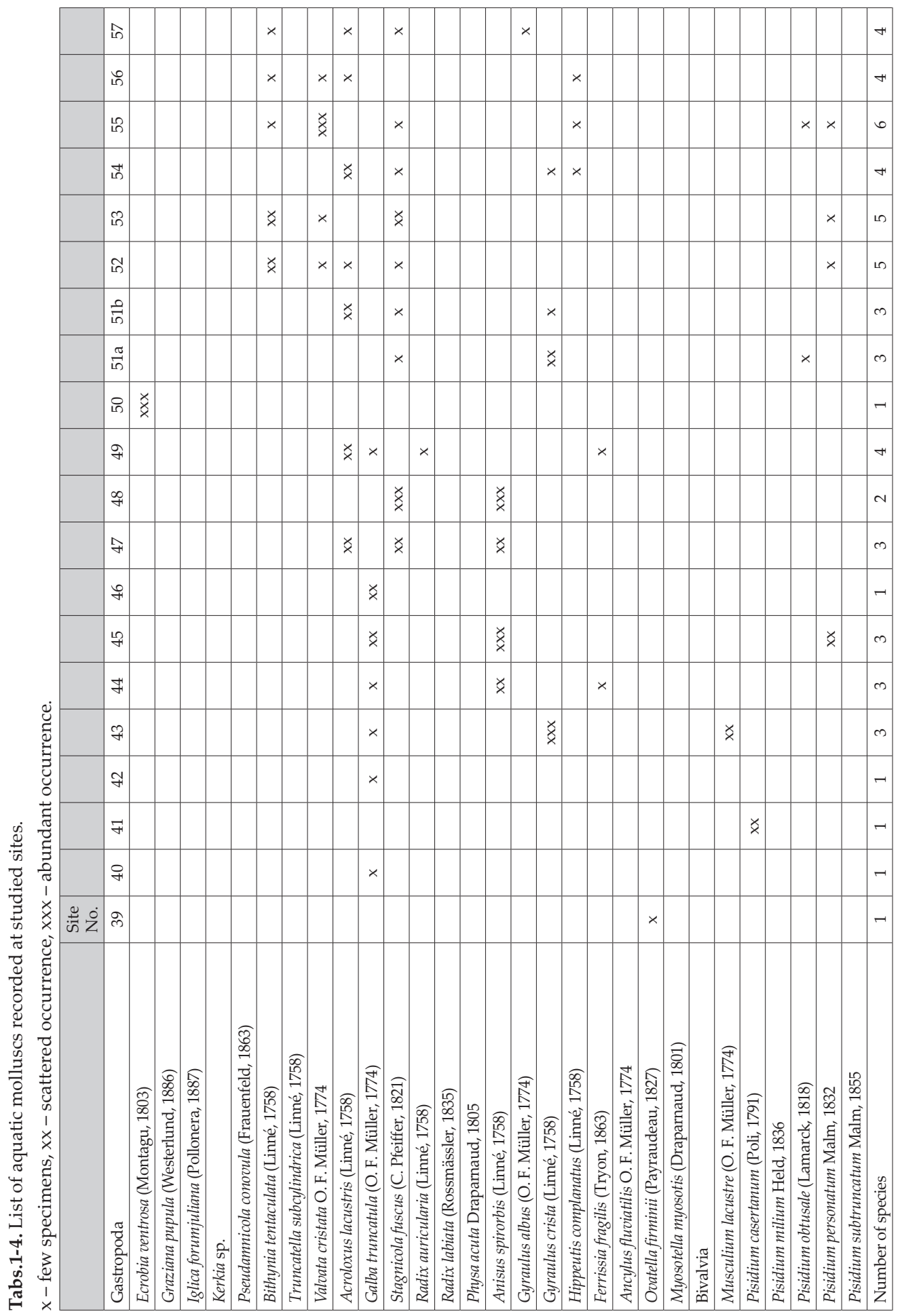




\begin{tabular}{|c|c|c|c|c|c|c|c|c|c|c|c|c|c|c|c|c|c|c|c|c|c|c|c|c|}
\hline & $\omega$ & & - & $-1-$ & -7 & $-\stackrel{2}{\sim}$ & 0 & - & in $\alpha$ & চ & $\approx$ & $\stackrel{m}{\rightarrow}$ & $\therefore-$ & $-\stackrel{2}{\sim}$ & $\infty$ & $0 m$. & $\cong 1$ & $\cap \infty$ & m & $\infty-$ & $-N$ & $\infty$ & $\infty-$ & \\
\hline & & $\mathbb{N}$ & & & & & & & & & & & & & & & & & $\begin{array}{l}x \\
x \\
x\end{array}$ & & & & & - \\
\hline & & $\Sigma$ & & & & & & & & $x$ & & & & $\times$ & & & & & & & & & & $N$ \\
\hline & & $R$ & & & & & & & & & & & $\stackrel{x}{x}$ & c. & & & & & & & & & & $\neg$ \\
\hline & & 8 & & & & & & & & & & $\times$ & & & & & $\stackrel{x}{x}$ & & & & & & & $N$ \\
\hline & & 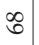 & & & & & & & & & & $\times$ & & & & & $\ddot{x}$ & & & & & & & $N$ \\
\hline & & 6 & & & & & $\overleftrightarrow{x}$ & & & $x$ & & & & $\check{x}$ & & & $\begin{array}{l}x \\
\grave{x}\end{array}$ & & & & & & & 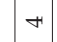 \\
\hline & & 8 & & & & & & $\times$ & & & & & & & & & & $\times$ & & & & & & $N$ \\
\hline & & 18 & & & & & & & & & & & & $\begin{array}{l}x \\
x \\
x\end{array}$ & & & & & & & & & & - \\
\hline & & t艹 & & & & & & & & & & & & $\begin{array}{l}x \\
x \\
x\end{array}$ & & & & & & & & & & $\neg$ \\
\hline & & 8 & & & & & & & & $x$ & $\times$ & & & $\begin{array}{l}x \\
\grave{x} \\
\end{array}$ & & & & & & $\times$ & & & $x$ & $<$ in \\
\hline & & $\widetilde{\sigma}$ & & & & & & & & & & & & $\stackrel{x}{x}$ & & & & & & & & & & -1 \\
\hline & & 5 & & & & & & & & & & & & $x$ & & & & & & & & & & -7 \\
\hline & & 8 & & & & & & & & & & & & $\underset{x}{x}$ & & & & & & & & & & - \\
\hline & & in & & & & & & & & & & & & $\stackrel{x}{x}$ & & & & & & & & & & -7 \\
\hline & & 冓 & & & & & & & $\times$ & & & & & $\stackrel{x}{x}$ & & & & & & & & & & $N$ \\
\hline & 菅之 & $\begin{array}{l}\text { 足 } \\
\stackrel{n}{n}\end{array}$ & & & & & & & & & $x$ & & & $\underset{x}{x}$ & & & & & & & & & & $N$ \\
\hline & & $\begin{array}{c}\frac{\pi}{0} \\
0 \\
0 \\
0 \\
0 \\
0 \\
0 \\
0\end{array}$ & 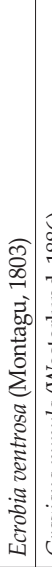 & 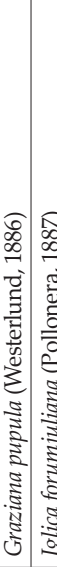 & 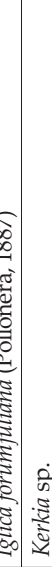 & 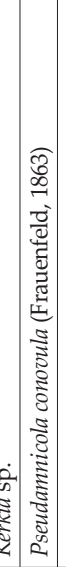 & 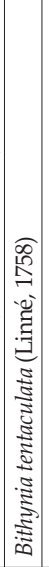 & 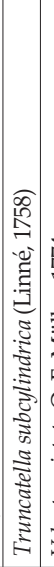 & 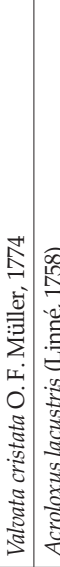 & 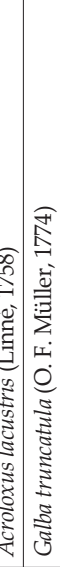 & 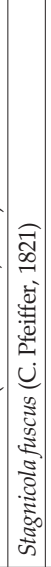 & 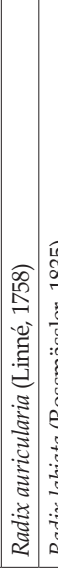 & 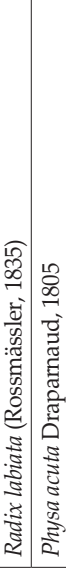 & 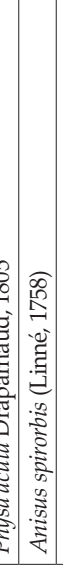 & 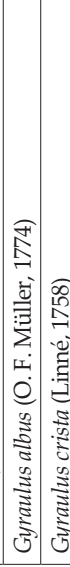 & 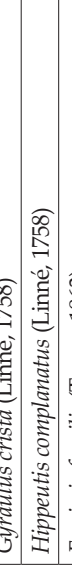 & 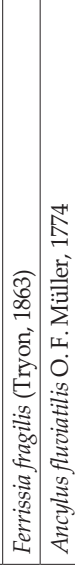 & 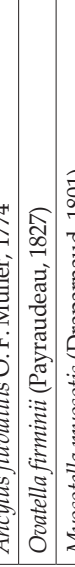 & 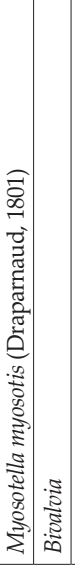 & 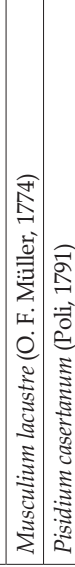 & 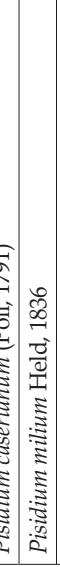 & 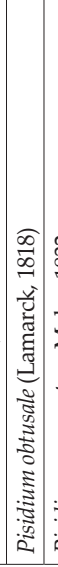 & 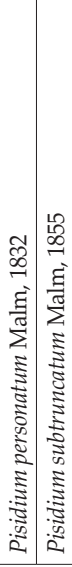 & 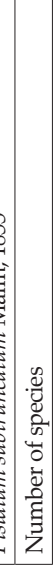 \\
\hline
\end{tabular}




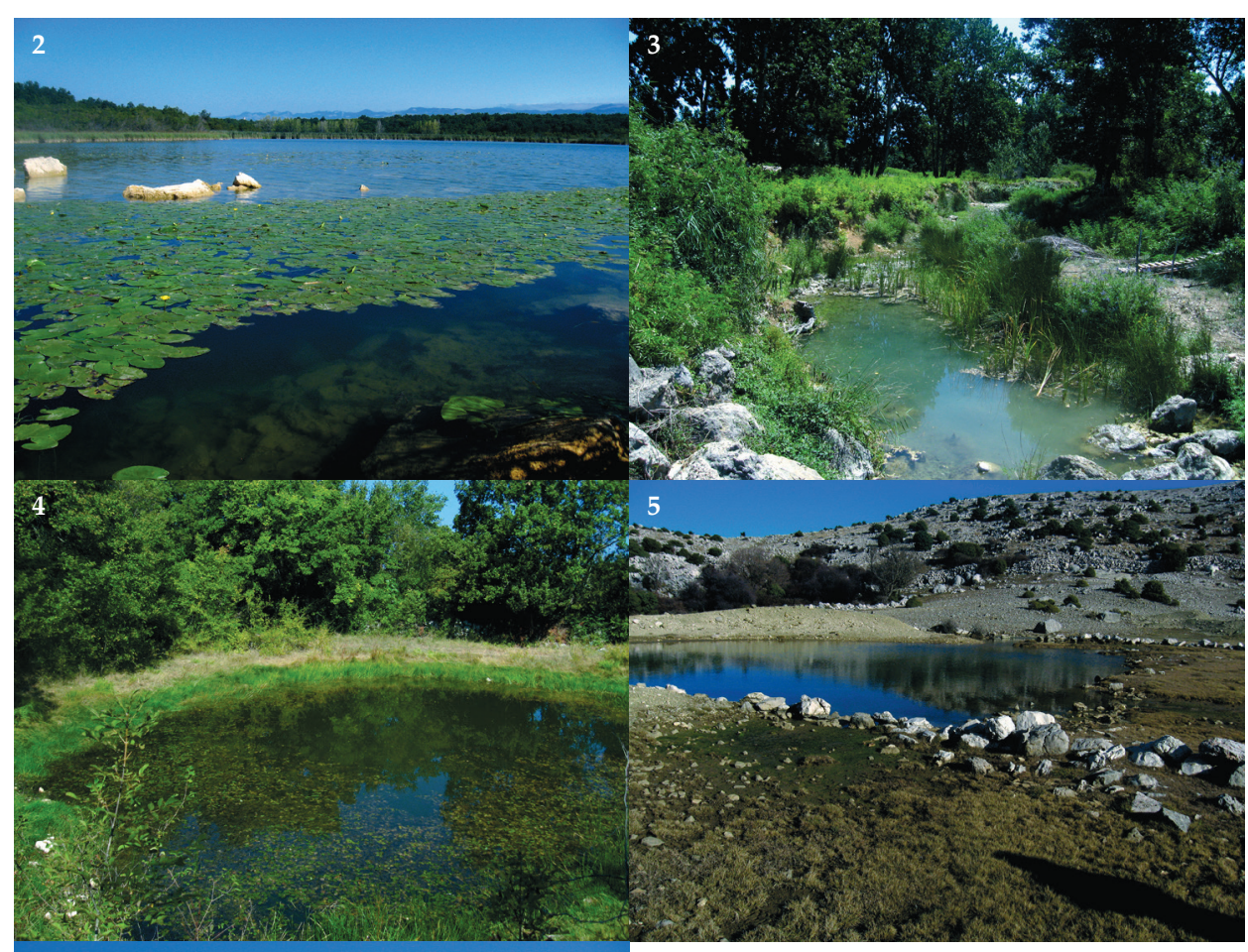

6

Fig. 2. Jezero Njivice lake (site 53) and its surroundings are inhabited with the most diversified assemblages of freshwater molluscs. All photos by L. Beran.

Fig. 3. The Ričica Brook (site 5) is the biggest watercourse on Krk Island.

Fig. 4. The pool Menkova Lokva near Poljica. Similar pools are a very common habitat at Krk Island (site 29).

Fig. 5. Some pools were without any aquatic molluscs (site 3 from App. 1).

Fig. 6. Rocky seacoast (site 66) is a suitable habitat for Ovatella firminii and Truncatella subcylindrica.

\section{DISCUSSION}

The detailed inventory of aquatic non-marine molluscs of Krk Island documented the occurrence of 28 species (18 freshwater and 4 brackish gastropods, 6 bivalves) and the number of recorded species is the highest known of the islands in the Adriatic Sea. Recent data for possible comparison are available from several nearby islands. Pag Island was found to be inhabited by14 species (BERAN, 2014) while 12 species are known from Rab Island (BERAN, 2015; ŠTAMOL et al., 2015). The amount of species recorded on Krk Island is consistent with its being the largest island in the Adriatic Sea, and also relatively close to the mainland. The significant reason for this richness is the existence of various habitats - lakes, temporary wetlands and ditches, pools, watercourses, springs and undeground waters, brackish habitats while at least some of them are 
missing on islands compared with it. Rab Island is poor in larger stagnant waterbodies while watercourses are nearly absent from Pag Island.

In the comparison with some other Croatian islands (Pag, Rab), small and isolated pools are very common freshwater habitats and are situated in different parts of Krk Island. Although these pools look like suitable habitats for freshwater molluscs (e. g. Figs. $4,5)$, their molluscan fauna is in reality very poor and usually consists of fewer than 3 species and many of the pools were without any molluscs. The isolation is the probable reason for their poverty in general. In some areas pools are much more frequent and relatively close to each other. They are to be found, for example, in the western part of this island near Porat, Poljica, Milohnić and Glavotok. In these pools the occurrence of at least one species was usually documented. By contrast, in the southern part of the island the pools are isolated and very often no occurrence of aquatic molluscs has been detected there. The possible reason for the absence of freshwater molluscs besides their isolation is also the higher altitude. Pools without positive findings are mentioned in App. 1.

The occurrence of 28 species confirmed with the recent research is significantly higher than the 7 non-marine aquatic species (Pseudamnicola conovula, Galba truncatula, Stagnicola fuscus, Radix auricularia, Gyraulus laevis, Musculium lacustre, Pisidium duplicatum) found by J. Bole about 60 years ago from 1950 to 1957 (Bole, 1958). Unfortunately, no specific data are mentioned there, so it is difficult to compare the results of the two surveys. Bole (1958) said that the results were obtained during 27 visits between 1950 and 1957 which looks quite comparable to current research but it is possible that much more effort and time was devoted to terrestrial molluscs. The species P. conovula, G. truncatula, S. fuscus, R. auricularia and Musculium lacustre found by J. Bole were found also during research conducted in the years 2015-2017. The name P. duplicatum is not a valid name or synonym of any recent bivalve so it is not exactly clear which species J. Bole found. However recent research confirmed the occurrence of 5 species of genus Pisidium (P. casertanum, P. milium, P. obtusale, P. personatum, P. subtruncatum) and so it is probable that the species identified by previous surveys was also found. The last mollusc found by Bole (1958) G. laevis was not found. J. Bole did not mention the specific site and it was not possible to check this record.

Physa acuta and Ferrissia fragilis are non-native aquatic molluscs recorded on Krk Island. The first species was also found on Rab Island (BERAN, 2015). This gastropod is known also from the mainland e. g. from the Krka River and its surroundings (BERAN, 2016). The finding of $F$. fragilis is the first known record of the occurrence of this species at least from the northern Croatian islands.

The survey of Krk Island has yielded interesting and valuable results that significantly supplement our knowledge of the molluscan assemblages of Croatian islands.

\section{ACKNOWLEDGEMENTS}

I would like to thank to Marco Bodon for his help with identification of three species (Graziana pupula, Iglica forumjuliana, Kerkia sp.). I am obliged to Helena Medková for preparing the map of Krk Island. 


\title{
REFERENCES
}

Beran, L., 2014: Contribution to the knowledge of non-marine aquatic molluscan fauna (Gastropoda, Bivalvia) of Pag Island (Croatia). Nat. Croat., 23(2), 303-313.

Beran, L., 2015: Non-marine aquatic molluscs (Gastropoda, Bivalvia) of Rab Island (Croatia). Nat. Croat., 24(2), 255-264.

BERAN, L., 2016: A contribution to knowledge of freshwater molluscs (Mollusca) of the Krka River in the Krka National Park (Croatia). Nat. Croat., 25(2), 295-304.

BoLe, J., 1958: Zoogeografski pregled malakofavne otoka Krka. [Zoogeographische übersicht der molluskenfauna der insel Krk]. - Bio. Vest., 6, 118-123.

Štamol, V., Slapnik, R., Vuković, M. \& KletečKi, E., 2015: Records of two non-marine snails new for Croatia (Mollusca: Gastropoda). - Nat. Croat., 24(2), 337-344.

\section{SUMMARY}

\section{Revision survey of non-marine aquatic molluscs (Gastropoda, Bivalvia) of Krk Island (Croatia)}

\author{
L. Beran
}

The survey of aquatic non-marine molluscs of the largest island in the Adriatic Sea done in the years 2015-2017 confirmed the occurrence of 28 species (18 freshwater and 4 brackish gastropods, 6 bivalves) at 72 sites. Fairly diversified molluscan assemblages with 4-6 species were found at only 15 sites. Probably the most diversified assemblages inhabit Jezero Njivice lake and its surroundings and rich communities were also confirmed from Ponikve lake. Different assemblages inhabit the Ričica Brook and its tributaries. The gastropods Graziana pupula, Iglica forumjuliana and Kerkia sp. were found only in the underground. Small and isolated pools are very common freshwater habitats and are situated in different locations on Krk Island but their molluscan fauna is very poor and usually consists of fewer than 3 species and situations in which no molluscs were found were not rare. Four species were found in brackish habitats. Two recorded species, Physa acuta and Ferrissia fragilis, belong to non-native species.

Previous research done about 60 years ago found out only 7 species. The results of this research were compared with the aquatic molluscan assemblages of two nearby islands and the number of recorded species is the highest known of the islands in the Adriatic Sea. The probable reason for this relatively high diversity is the existence of various habitats together with the facts that it is the largest island in the Adriatic Sea, and also relatively close to the mainland. 
Appendix 1. List of pools in which aquatic molluscs were not found

\begin{tabular}{|c|c|l|}
\hline $\begin{array}{c}\text { site } \\
\text { no. }\end{array}$ & $\begin{array}{c}\text { geographical } \\
\text { coordinates }\end{array}$ & \multicolumn{1}{|c|}{ site description, date of investigation } \\
\hline 1 & $\begin{array}{c}45^{\circ} 00^{\prime} 07.4^{\prime \prime} \mathrm{N}, \\
14^{\circ} 46^{\prime} 03.4^{\prime \prime} \mathrm{E}\end{array}$ & Jurandvor, a pool Diviška below the hill Diviška (471 m a. s. 1.), 29.12.2016 \\
\hline 2 & $\begin{array}{c}45^{\circ} 00^{\prime} 12.4^{\prime \prime} \mathrm{N}, \\
14^{\circ} 45^{\prime} 00.8^{\prime \prime} \mathrm{E}\end{array}$ & $\begin{array}{l}\text { Jurandvor, a concrete pool by the dirt road to the west of Diviška (471 m a. s. } \\
1 .), 29.12 .2016\end{array}$ \\
\hline 3 & $\begin{array}{c}45^{\circ} 00^{\prime} 30.2^{\prime \prime} \mathrm{N}, \\
14^{\circ} 40^{\prime} 57.3^{\prime \prime} \mathrm{E}\end{array}$ & $\begin{array}{l}\text { Draga Bašćanska, three pools (Vela Lokva) to the east of Veli Vrh (541 m a. s. } \\
\text { 1.), 27.12.2016 }\end{array}$ \\
\hline 4 & $\begin{array}{c}45^{\circ} 00^{\prime} 42.6^{\prime \prime} \mathrm{N}, \\
14^{\circ} 40^{\prime} 31.8^{\prime \prime} \mathrm{E}\end{array}$ & $\begin{array}{l}\text { Draga Bašćanska, a small pool (Kaljužina) to the north of Veli Vrh (541 m a. s. } \\
1 .), 27.12 .2016\end{array}$ \\
\hline 5 & $\begin{array}{c}45^{\circ} 02^{\prime} 26.1^{\prime \prime} \mathrm{N}, \\
14^{\circ} 43^{\prime} 54.9^{\prime \prime} \mathrm{E}\end{array}$ & $\begin{array}{l}\text { Draga Bašćanska, an extensive pool to the southeast of Vranjak (350 m a. s. 1.), } \\
\text { Fig. 5, 28.12.2016 }\end{array}$ \\
\hline 6 & $\begin{array}{c}45^{\circ} 02^{\prime} 34.6^{\prime \prime} \mathrm{N}, \\
14^{\circ} 42^{\prime} 12.1^{\prime \prime} \mathrm{E}\end{array}$ & $\begin{array}{l}\text { Draga Bašćanska, a concrete pool (tank) to the southeast Vranjak (350 m a. s. } \\
\text { 1.), 27.12.2016 }\end{array}$ \\
\hline 7 & $\begin{array}{c}45^{\circ} 04^{\prime} 57.9^{\prime \prime} \mathrm{N}, \\
14^{\circ} 29^{\prime} 52.1^{\prime \prime} \mathrm{E}\end{array}$ & $\begin{array}{l}\text { Poljica, a restored pool ca } 100 \mathrm{~m} \text { from a dirt road to the southeast of Poljica, } \\
29.8 .2016\end{array}$ \\
\hline 8 & $\begin{array}{c}45^{\circ} 10^{\prime} 12.9^{\prime \prime} \mathrm{N}, \\
14^{\circ} 36^{\prime} 20.2^{\prime \prime} \mathrm{E}\end{array}$ & $\begin{array}{l}\text { Čižići, an extensive pool pool and wetland by the road Čižići - Rudine, } \\
26.12 .2016\end{array}$ \\
\hline 9 & $\begin{array}{c}45^{\circ} 10^{\prime} 51.6^{\prime \prime} \mathrm{N}, \\
14^{\circ} 37^{\prime} 02.1^{\prime \prime} \mathrm{E}\end{array}$ & \begin{tabular}{l} 
Rudine, a pool to the southeast of Rudine, 26.12.2016 \\
\hline
\end{tabular} \\
\hline
\end{tabular}

